\title{
Analysis of Students' Mathematical Representation Ability In Understanding the Material System of Linear Equations of Two Variables
}

\author{
Analisis Kemampuan Representasi Matematis Siswa \\ Dalam Memahami Materi Sistem Persamaan Linear Dua Variabel
}

\author{
Lala Intan Komalasari \\ doi: https://doi.org/10.51518/lentera.v3i2.51 \\ email: lalaintankomalasari@mail.com
}

Dosen pada STKIP Al-Amin Dompu

\begin{abstract}
The purpose of this study was to analyze the mathematical representation ability of eighth grade students of SMP Negeri 02 Woja in understanding the material for the Two-variable Linear Equation System. The method used in this research is descriptive method. The descriptive method uses descriptive statistics to process the data obtained from the research results. In addition, the researchers conducted interviews with mathematics teachers who directly taught class VIII students in order to strengthen the data obtained in addition to tests. The findings of this study are as follows: The overall mathematical representation ability of students has an average score of 59.87; The ability of mathematical representation on the pictorial representation has an average of 50.98. The ability of mathematical representation on the symbol representation indicator has an average of 65.66 . Mathematical representation ability on verbal representation indicators has an average of 62.45 .
\end{abstract}

Keywords: Mathematical Representation, Two Variable Linear Equations

\begin{abstract}
Abstrak. Tujuan dari penelitian ini adalah untuk menganalisis kemampuan representasi matematis siswa kelas VIII SMP Negeri 02 Woja dalam memahami materi Sistem Persamaan Linear Dua Variabel. Metode yang digunakan dalam penelitian adalah metode deskriptif. Pada metode deskriptif menggunakan statistika desrkriptif untuk mengolah data yang diperoleh dari hasil penelitian. Selain itu, peneliti melakukan wawancara kepada guru matematika yang mengajar langsung siswa-siswa kelas VIII guna memperkuat datadata yang diperoleh selain tes. Temuan penelitian ini adalah sebagai berikut: Kemampuan representasi matematis siswa secara keseluruhan memiliki nilai rata-rata sebesar 59,87; Kemampuan representasi matematis pada indikator representasi gambar (pictorial representation) memiliki rata-rata sebesar 50,98. Kemampuan
\end{abstract}


representasi matematis pada indikator representasi symbol (symbolic representation) memiliki rata-rata sebesar 65,66. Kemampuan representasi matematis pada indikator representasi verbal (verbal representation) memiliki rata-rata sebesar 62,45.

Kata Kunci: Representasi Matematis, Persamaan Linear Dua Variabel

\section{A. PENDAHULUAN}

Matematika merupakan peranan yang penting dalam menunjang perkembangan ilmu pengetahuan dan teknologi. Oleh karena itu sampai batas tertentu matematika hendaknya dikuasai dengan baik oleh setiap individu. Penguasaan ilmu matematika perlu dilakukan semenjak dini dimulai dari masa awal pendidikan seorang anak. Seorang anak yang telah masuk pada jenjang pendidikan formal di sekolah perlu mendapat perhatian khusus dalam perkembangannya mempelajari matematika (Nurharini, et.al, 2008; Komalasari, 2020).

Kemampuan yang dihasilkan dari pelajaran matematika tersebut menghasilkan kemampuan berpikir logis, sistematis, analisis, inovatif, kreatif dan lain-lain yang menjadi dasar yang diperlukan untuk membuat berbagai inovasi di dalam perkembangan ilmu pengetahuan dan tekhnologi (Pape dan tchoshanov, 2001; Villages, et.al, 2009; Nurharini, et.al, 2008; Komalasari, 2020). Untuk mewujudkan harapan tersebut maka setiap siswa perlu dibekali kemampuan matematis yang matang agar nantinya dapat dengan baik mengintegrasikan kemampuan matematis mereka ke dalam disiplin ilmu pengetahuan lainnya. Peran guru dan lembaga pendidikan menjadi sangat penting dalam mengembangkan kemampuan matematis siswa sebagai perserta didik.

Kemampuan representasi menjadi salah satu kemampuan yang harus dimiliki oleh setiap siswa dalam pembelajaran matematika sebagaimana disebutkan dalam tujuan pembelajaran matematika menurut Permendiknas tersebut (Lawshe, 1975). Hal tersebut dikuatkan oleh National Council of Teachers of Mathematics (NCTM) (2000) yang menyebutkan bahwa kemampuan representasi termasuk salah satu standar proses dalam pembelajaran matematika. "The next five Standards address theprocesses of problem solving, reasoning and proof, connections, communication, and representation". NCTM menetapkan terdapat lima standard proses kemampuan matematis yang siswa butuhkan. Kemampuan yang perlu dimiliki oleh siswa meliputi kemampuan pemecahan masalah (Problem Solving), kemampuan berargumentasi (Reasoning and Proof), kemampuan berkomunikasi (Communication), kemampuan menggunakan koneksi (Connections), dan kemampuan representasi (Representation).

Berdasarkan uraian tersebut, representasi dalam pembelajaran matematika merupakan kemampuan yang harus dimiliki oleh siswa. Kemampuan representasi sangat penting dimiliki oleh siswa karena mampu mempermudah siswa mempelajari matematika, sebagaimana pernyataan NCTM sebagai berikut:

Representation is central to the study of mathematics. Students candevelop and deepen their understanding of mathematical concepts andrelationships as they create, compare, and use various 
representations. Representations-such as physical objects, drawings, charts, graphs, and symbols-also help students communicate their thinking. (NCTM. 2000:280).

Representasi adalah pusat dari pembelajaran matematika. Siswa dapat mengembangkan, memperdalam pemahaman mereka akan konsep dan hubungan antarkonsep matematika membandingkan dan yang telah menggunakan mereka miliki representasi (Hardianingsih, 2017; Kartini, 2009). Melalui Mengenai membuat, pentingnya kemampuan representasi di dalam matematika Verschaffel dan kawan-kawan (2010:1) dalam bukunya menjelaskan,

As a result of recent development in information and communication technology (ICT), the use of (external) representation in information processing, communicating and learning and teaching has increased dramatically. Nowadays, learners must be able to interpret and use a large of variety of (external) representational forms and tools both for their own reasoning, problem solving, and learning and communicating with others.

Berdasarkan pendapat di atas, sebagai hasil dari perkembangan tekhnologi informasi dan komunikasi, penggunaan representasi dalam mengolah informasi, komunikasi dan pembelajaran berkembang dengan pesat. Representasi yang dimaksud adalah representasi eksternal (Hardianingsih, 2017). Pada masa seperti ini, para siswa harus mampu menginterpretasikan dan menggunakan berbagai macam representasi eksternal dan perangkatnya untuk penalaran, pemecahan masalah, dan pembelajaran bagi diri sendiri maupun sebagai media berkomunikasi atas pemahaman yang didapat kepada orang lain (Hardianingsih, 2017; Kartini, 2009)

Kemampuan representasi yang dikuasai dengan baik akan membantu siswa dalam mempelajari matematika sehingga akan dapat mempengaruhi hasil belajarnya (Hardianingsih, 2017; Komalasari,2020). Rendahnya kemampuan representasi matematis siswa dapat menjadi salah satu penyebab rendahnya hasil belajar siswa pada pemebelajaran matematika (Hardianingsih, 2017).

Sebagaimana studi yang dilakukan oleh TIMSS dan PISA yang dilakukan di beberapa Negara termasuk salah satunya Indonesia, menyebutkan bahwa representasi termasuk salah satu aspek dalam penilaian literasi matematika (Gagatis. et.al, 2004). Hasil studi tersebut menyebutkan bahwa tingkat keberhasilan pembelajaran matematika di Indonesia masih tergolong rendah. Indonesia mengikuti TIMSS pada tahun 1999, 2003 dan 2007 dan PISA tahun 2000, 2003, 2006, 2009 dengan hasil tidak menunjukkan banyak perubahan pada setiap keikutsertaan (Lestari, et.al, 2015; Godino dan Font 2010; Goldin. Et.al, 2010). Pada PISA tahun 2009 Indonesia hanya menduduki rangking 61 dari 65 peserta dengan rata-rata skor 371 , sementara rata-rata skor internasional adalah 496. Prestasi pada TIMSS 2007 lebih memprihatinkan lagi, karena rata-rata skor siswa kelas 8 kita menurun menjadi 405, dibanding tahun 2003 yaitu 411 . Rangking Indonesia pada TIMSS tahun 2007 menjadi rangking 36 dari 49 negara (Sri Wardhani, 2011) 
Contoh lain misalnya kesulitan dalam membuat gambar ilustrasi dari sebuah permasalahan dari kehidupan nyata yang mengharuskan siswa membuat gambar terlebih dahulu agar bisa mencari penyelesaian masalah, jika siswa tidak mampu menyajikan permasalahan tersebut dalam bentuk gambar maka siswa akan mengalami kesulitan dalam mencari penyelesaian dari permasalahan tersebut. Kesulitan siswa dalam memahami masalah matematika yang berkaitan dengan menggambar dan membaca grafik dapat ditemukan pada materi system persamaan linear dua variabel. Hasil temuan Erdy Poernomo (2014) di dalam skripsinya yang berjudul "Pengaruh Pembelajaran Kooperatif Strategi Think-TalkWrite Menggunakan Masalah Kontekstual Terhadap Kemampuan Representasi Matematis Siswa" yang dilaksanakan di SMP Negeri 4 Tangerang Selatan tahun ajaran 2013/2014 menunjukkan bahwa kemampuan representasi matematis siswa dalam bentuk gambar masih rendah dibandingkan kemampuan representasi simbol dan verbal. Siswa yang mampu mencapai indikator pictorial representation pada kelompok eksperimen hanya sebesar $60,41 \%$ dan kelompok kontrol sebesar $7,52 \%$, nilai tersebut berada dibawah hasil pencapaian siswa pada indikator symbolic representationsebesar $85.93 \%$ pada kelompok eksperimen dan $50.26 \%$ pada kelompok kontrol. Begitu pun untuk indikator verbal representation sebesar $71.61 \%$ pada kelompok eksperimen dan $21.50 \%$ pada kelompok kontrol, hasil tersebut masih lebih tinggi dari hasil untuk indikator pictorial representation (Erdy Poernomo. 2014).

Berdasarkan penjelasan tersebut, representasi dalam bentuk gambar menjadi penting untuk diperhatikan mengingat salah satu kesulitan siswa dalam belajar. Erdy Poernomo, "Pengaruh Pembelajaran Kooperatif Strategi Think-TalkWrite Menggunakan Masalah Kontekstual Terhadap Kemampuan Representasi Matematis Siswa", matematika dapat dikarenakan kurangnya kemampuan representasi dalam bentuk gambar.

Kesulitan-kesulitan siswa dalam mempelajari matematika juga ditemukan pada bentuk reresentasi lainnya. Berdasarkan pengamatan yang dilakukan peneliti ketika melaksanakan observasi pada kegiatan Praktik Profesi Keguruan Terpadu yang bertempat di SMP Negeri 02 Woja, metode pengajaran yang dilakukan guru pada saat mengajar matematika cenderung langsung memberikan rumus kepada siswa, tidak terlebih dahulu mengaitkan dengan kehidupan nyata atau situasi yang dialami oleh siswa. Dengan metode seperti itu, siswa berpikir bahwa matematika adalah sesuatu yang abstrak, sulit untuk dipahami dan sulit dijumpai aplikasinya pada kehidupan sehari-hari. Selain itu ketika guru memberikan latihan soal, soal yang diberikan cenderung berupa soal uraian objektif atau soal objektif yang berupa fakta angka dan biasanya soal yang diberikan hanya berupa penyelesaian dalam bentuk representasi simbolik saja. Oleh karena itu, kemampuan representasi dalam bentuk gambar dan verbal masih kurang terasah dan siswa lebih banyak menggunakan bentuk representasi simbolik ketika menyelesaikan suatu masalah.

Berdasarkan latar belakang yang telah disampaikan tersebut, peneliti tertarik untuk melakukan penelitian dengan judul : "Analisis Kemampuan Representasi Matematis Siswa dalam Memahami Materi Sistem Persamaan Linear Dua Variabel Kelas VIII SMP Negeri 02 Woja Tahun Pelajaran 2019/2020". 


\section{B. METODE PENELITIAN}

Metode yang digunakan dalam penelitian adalah metode deskriptif. Pada metode deskriptif menggunakan statistika desrkriptif untuk mengolah data yang diperoleh dari hasil penelitian. Statistika deskriptif adalah statistik yang berkenaan dengan bagaimana cara mendeskripsikan, menggambarkan, menjabarkan, atau menguraikan data sehingga mudah dipahami (Syofian Siregar, 2010; Arikunto, 2006). Adapun cara yang digunakan untuk mendiskripsikan, menggambarkan, menjabarkan, atau menguraikan data dalam penelitian ini adalah dengan menentukan ukuran dari data seperti nilai modus, rata-rata dan nilai tengah (median) dan menentukan ukuran variabilitas data seperti variasi (varian), tingkat penyimpangan (deviasi standar) dan jarak (range) (Arikunto, 2006). Selain itu, peneliti melakukan wawancara kepada guru matematika yang mengajar langsung siswa-siswa kelas VIII guna memperkuat data-data yang diperoleh selain tes.

Populasi target dalam penelitian ini adalah siswa kelas VIII SMP Negeri 02 Woja. Penentuan sampel dilakukan dengan menggunakan teknik Simple Random Sampling. Hal ini dapat dilakukan karena populasi target kelas VIII di SMP Negeri 02 Woja yang dipilih adalah siswa kelas VIII regular, sehingga dapat diasumsikan homogen.

Teknik pengumpulan data dalam penelitian ini menggunakan beberapa cara/teknik yaitu tes dan wawancara: Tes, digunakan sebagai upaya untuk memperoleh data primer tentang kemampuan representasi matematis siswa pada materi Sistem Persamaan Linear Dua Variabel. Tes yang digunakan dalam penelitian ini adalah tes berbentuk uraian. Wawancara, digunakan sebagai teknik pendukung di samping tes untuk memperoleh gambaran dalam menganalisis kemampuan representasi matematis siswa pada materi Sistem Persamaan Linear Dua Variabel.

\section{HASIL DAN PEMBAHASAN}

Penelitian ini bertujuan untuk mengetahui kemampuan representasi matematis siswa kelas VIII di SMP Negeri 2 Woja pada materi Sistem Persamaan Linear Dua variabel. Penelitian ini dilakukan pada siswa kelas VIII yang berjumlah 85 orang sebagai sampel. Penelitian ini dilakukan pada bulan Januari semester genap tahun pelajaran 2019/2020. Pengambilan data dilakukan melalui tes tertulis dan wawancara selama penelitian berlangsung. Tes yang diberikan pada siswa dalam bentuk soal uraian (essay) materi Sistem Persamaan Linear Dua Variabel.

Data hasil penelitian diperoleh dari hasil tes kemampuan representasi matematis siswa berdasarkan indikator representasi gambar (pictorial representation), representasi simbol (symbolic representation), dan representasi kata-kata (verbal representation). Data-data tersebut kemudian dianalisis dan disajikan dalam bentuk deskripsi sebagai gambaran hasil penelitian. 
Tabel 4. 1

Data jumlah kelas, rombel dan siswa TP 2019/2020

\begin{tabular}{cccccc}
\hline \multirow{2}{*}{ No. } & Data Kelas & Jumlah & \multicolumn{3}{c}{ Jumlah Siswa } \\
\cline { 4 - 6 } & Kombel & Laki-laki & Perempuan & Jumlah \\
$\mathbf{1}$ & Kelas VII & 4 & 61 & 112 & 173 \\
$\mathbf{2}$ & Kelas VIII & 3 & 57 & 77 & 134 \\
$\mathbf{3}$ & Kelas IX & 3 & 36 & 67 & 103 \\
& JUMLAH & $\mathbf{1 0}$ & $\mathbf{1 5 4}$ & $\mathbf{2 5 6}$ & $\mathbf{4 1 0}$ \\
\hline
\end{tabular}

Pada penelitian ini, kelas yang dijadikan subjek penelitian adalah kelas reguler tingkat kelas VIII sebanyak tiga kelas. Sampel masing-masing $10-12$ orang per kelas sehingga jumlah sampel terpilih adalah 35 orang siswa.

\section{Penyajian Data}

\section{Kemampuan Representasi Matematis Siswa Keseluruhan}

Berdasarkan data yang telah diperoleh dari lapangan, agar mudah dipahami maka dideskripsikan ke dalam berbagai bentuk penyajian. Penyajian data pada penelitian ini dengan menggunakan tebel distribusi frekuensi dan grafik. Data hasil penelitian tes kemampuan representasi matematis siswa secara keseluruhan disajikan dalam bentuk sebagai berikut :

Tabel 4. 2 Statistik Deskriptif Kemampuan Representasi Matematis

\begin{tabular}{cc} 
Statistika & Hasil \\
\hline Jumlah sampel (N) & 85 \\
Mean (X) & 59,84 \\
Median (Me) & 63,0 \\
Modus (Mo) & 64,83 \\
Varians (S2) & 164,8941 \\
Simpangan Baku (S) & 12,84 \\
\hline
\end{tabular}

Pada Tabel 4.2 terlihat bahwa rata-rata kemampuan representasi matematis siswa sebesar 59,84, sehingga berdasarkan Tabel 3.12 maka termasuk dalam kategori sedang. Median (Me) dari data yaitu 63,0. Modus (Mo) dari data yaitu 64,83 . Varian hasil uji statistika 164,8941 , menandakan jarak pesebaran skor hasil penelitian terhadap rata-rata.

Simpangan baku (S) hasil uji statistika 12,84, menandakan keragaman skor hasil tes siswa.

Berikut ini akan disajikan tabel frekuensi kemampuan representasi matematis pada data keseluruhan:

Tabel 4. 3

Distribusi Frekuensi Kemampuan Representasi Matematis

\begin{tabular}{ccccc}
\hline & & \multicolumn{3}{c}{ Frekuensi } \\
\cline { 3 - 5 } No. & Interval & Absolut & Relatif & $\begin{array}{c}\text { Relatif } \\
\text { Kumulatif }\end{array}$ \\
& & 3 & 5,88 & 5,88 \\
$\mathbf{1}$ & $33-40$ & 8 & 24,71 & 30,59 \\
$\mathbf{2}$ & $41-48$ & - & - & 30,59 \\
\hline
\end{tabular}

42| Edisi 3 No. 2 Januari-Juli 2021 


\begin{tabular}{lcccc}
\hline $\mathbf{4}$ & $57-64$ & 11 & 30,59 & 61,18 \\
$\mathbf{5}$ & $65-72$ & 6 & 21,18 & 82,35 \\
$\mathbf{6}$ & $73-80$ & 5 & 15,29 & 97,65 \\
$\mathbf{7}$ & $81-87$ & 2 & 2,35 & 100,00 \\
& Jumlah & $\mathbf{3 5}$ & 100,00 & \\
\hline
\end{tabular}

Berdasarkan Tabel 4.3 dapat diketahui bahwa nilai yang paling banyak diperoleh siswa berada pada interval 57 - 64 yaitu sebesar 30,59\% (11 siswa dari 35 siswa). Perbedaan yang cukup signifikan terlihat dari kelas interval frekuensi tertinggi dengan kelas interval frekuensi terrendah. Selisih frekuensi relatif pada interval 4 dan interval 7 yaitu sebesar $28,24 \%$. Dari sebanyak 3 kelas interval yang ada, hanya kelas interval 49 - 56 yang tidak terdapat frekuensi, ini berarti tidak ada siswa yang mendapat nilai dari 49 sampai 56, tetapi pada dua kelas interval sebelum dan sesudahnya merupakan dua kelas interval dengan frekuensi terbanyak.

\section{Kemampuan Representasi Matematis Siswa Berdasarkan Indikator}

Selain berdasarkan jumlah frekuensi keseluruhan dapat juga dibentuk table dan diagram berdasarkan nilai rata-rata tiap indikator representasi matematis. Berikut ini adalah tabel nilai rata-rata indikator representasi matematis :

Tabel 4. 4.

\begin{tabular}{|c|c|c|c|c|}
\hline \multirow[b]{2}{*}{ No. } & \multirow{2}{*}{$\begin{array}{c}\text { Aspek Indikator } \\
\text { Kemampuan } \\
\text { Representasi } \\
\text { Matematis }\end{array}$} & \multicolumn{3}{|c|}{ Skor } \\
\hline & & $\begin{array}{c}\text { Skor } \\
\text { Maks/Ideal }\end{array}$ & $\mathbf{x}$ & $\%$ \\
\hline 1 & Pictoral Representation & 3 & 1,53 & 50,98 \\
\hline 2 & Symbolic Reresentation & 6 & 3,94 & 65,66 \\
\hline 3 & Verbal Representation & 6 & 3,75 & 62,45 \\
\hline
\end{tabular}

Berdasarkan Tabel 4.3 diketahui bahwa indikator representasi gambar (Pictorial Representation) mempunyai skor ideal 3 karena mempunyai satu soal, sedangkan indikator representasi symbol (Symbolic Reresentation) dan representasi verbal (Verbal Representation) memiliki skor ideal 6 karena memiliki dua soal. Tiap soal memiliki skor maksimum 3. Hasil analisa data menunjukan nilai tertinggi adalah indikator representasi simbol (Symbolic Representation) dengan skor rata-rata 3,94 dari skor maksimal $6(65,66 \%)$, menandakan bahwa sebagian siswa dinyatakan mampu menyelesaikan permasalahan matematika menggunakan model matematika. Sedangkan skor terrendah adalah indikator representasi gambar (Pictorial Representation) dengan skor rata-rata 1,53 dari skor maksimal 3 $(50.98 \%)$, dapat dikatakan kemampuan siswa dalam menyelesaikan permasalahan matematika menggunakan representasi dalam bentuk gambar tidak sebaik menggunakan representasi simbol dan verbal. Selisih nilai rata-rata tertinggi dan terrendah yaitu indikator representasi symbol (Symbolic Reresentation) dan representasi gambar (Pictorial Representation) hanya sebesar 14,68. Berdasarkan kriteria pada Tabel 3.12, nilai rata-rata masingmasing 
indikator representasi matematis pada Tabel 4.4, ketiganya termasuk dalam kategori sedang.

Dari tabel diatas, dapat juga disajikan dalam bentuk diagram batang berikut ini :

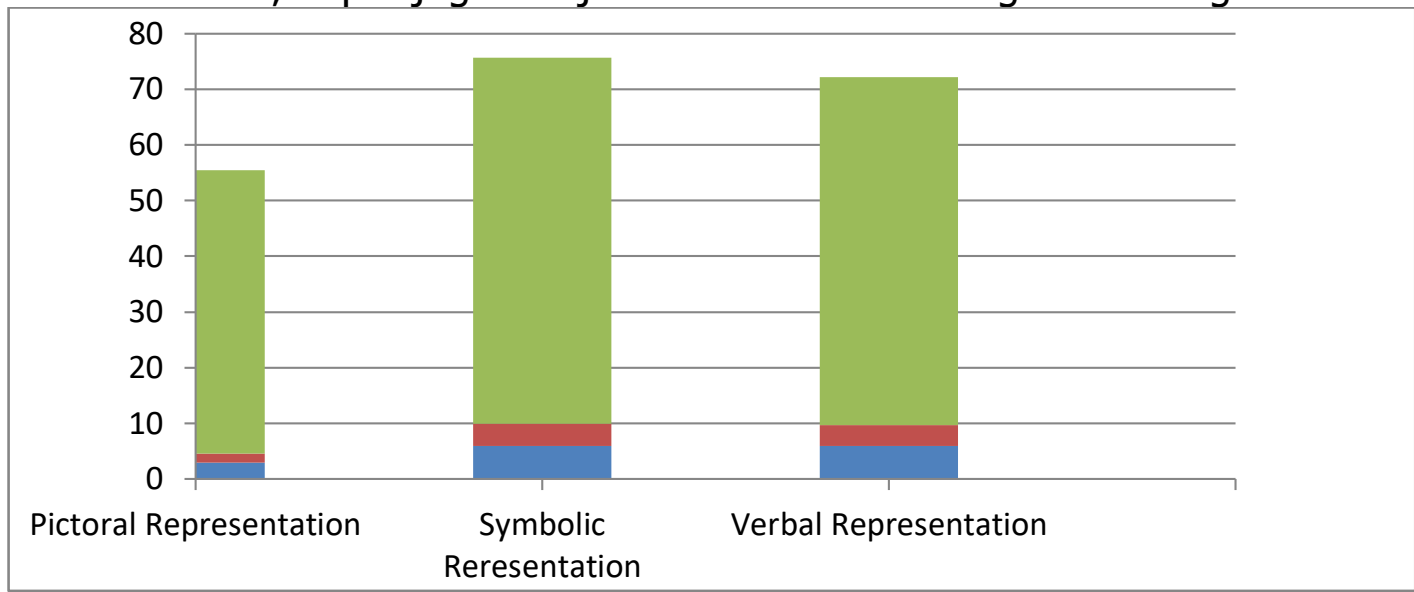

Gambar 4. 1 Nilai Rata-rata Per Indikator Representasi Matematis

Dari Gambar 4.1 terlihat bahwa terlihat bahwa ketiga indikator tersebut memiliki nilai rata-rata yang tidak terlalu jauh berbeda. Nilai rata-rata indikator representasi simbol (Symbolic Representation) lebih besar dari nilai rata-rata indikator representasi verbal (Verbal Representation) dan representasi gambar (Pictorial Representation) pada materi sistem persamaan linear dua variabel . Artinya sebagian besar siswa sudah mampu menyelesaikan permasalahan matematika dengan mengubah permasalahan matematika menjadi bentuk simbol-simbol dan membuat model matematikannya.

\section{Pembahasan}

Penelitian ini dilakukan pada siswa yang telah mempelajari materi system persamaan linear dua variabel di kelas VIII SMP Negeri 2 Woja tahun pelajaran 2019/2020 semester genap. Berdasarkan tabel distribusi frekuensi yang disajikan pada Tabel 4.1 diperoleh nilai rata-rata kemampuan represenatsi matematis siswa kelas VIII SMP Negeri 2 Woja tahun pelajaran 2019/2020 pada materi Sistem Persamaan Linear Dua Variabel adalah 59,84. Berdasarkan nilai rata-rata keseluruhan indikator representasi matematis tersebut, dapat peneliti simpulkan bahwa kemampuan reprsentasi matematis siswa dalam bentuk gambar masih tergolong kurang memuaskan karena nilai rata-rata indikator tersebut berada dibawah nilai rata-rata keseluruhan. Perbedaan cara menjawab soal siswa untuk masing-masing indikator kemampuan representasi matematis dideskripsikan sebagai berikut:

\section{Kemampuan representasi gambar (Pictorial Representation)}

Soal yang memperlihatkan bagaimana kemampuan representasi matematis dalam bentuk gambar adalah butir soal nomor 3. Sebagai gambaran umum berikut ini disajikan soal nomor 3 serta jawaban beberapa siswa dalam menjawab pertanyaan soal nomor 3.

Pertanyaan nomor 3: Ryan dan Rizky mempunyai beberapa kelereng.

Himpunan penyelesaian dari jumlah kelereng Ryan dan Rizki dituliskan dalam sebuah tabel berikut : 


\begin{tabular}{ccc}
\hline Ryan & $\mathbf{0}$ & $\mathbf{1 0}$ \\
\hline Rizki & 10 & 0 \\
$(\mathbf{x}, \mathbf{y})$ & $(0,10)$ & $(10,0)$ \\
\hline
\end{tabular}

Himpunan penyelesaian dari selisih kelereng Ryan dan Rizki dituliskan dalam sebuah tabel berikut :

\begin{tabular}{ccc}
\hline Ryan & $\mathbf{0}$ & $\mathbf{4}$ \\
\hline Rizki & -4 & 0 \\
$(\mathbf{x}, \mathbf{y})$ & $(0,-4)$ & $(4,0)$ \\
\hline
\end{tabular}

Berapakah masing-masing kelereng Ryan dan Rizky?

Berikut diberikan contoh jawaban yang diberikan oleh beberapa siswa: Pada Gambar 4.2 pada jawaban siswa yang mendapat skor 3 terlihat bahwa siswa mampu membuat gambar grafik dengan baik. Ketepatan dalam menentukan titik dan membuat garis serta menentukan titik potong serta menyelesaikan/mencari solusi dari permasalahan pada soal nomor 3, yaitu mencari banyaknya kelereng yang dimiliki Ryan dan banyaknya kelereng yang dimiliki Rizki. Terlihat siswa sudah memahami cara membuat koordinat kartesius untuk menentukan titik pada grafik dan memahami konsep bilangan bulat serta garis bilangan untuk menggambar sumbu $x$ dan sumbu $y$. Hal ini menunjukkan bahwa siswa mampu mengubah simbol-simbol matematis ke dalam bentuk gambar atau grafik.

Pada jawaban siswa yang mendapatkan skor 2 dalam menjawab soal nomor 3 terdapat kesalahan siswa dalam menjawab yaitu dalam menentukan titiktitik pada gambar atau grafik yang telah mereka buat sehingga tidak bias menentukan titik potong kedua garis. Kesalahan tersebut terlihat pada langkah menentukan titik $(0,-4)$. Siswa salah menempatkan titik -4 sumbu y tersebut pada sumbu $x$. Siswa tidak mampu mengubah pasangan himpunan $(a, b)$ yang terdapat unsur bilangan negatif ke dalam bentuk gambar koordinat titik $(x, y)$. Hal ini menunjukkan bahwa kemampuan representasi matematis siswa dalam bentuk gambar masih kurang memuaskan.

Pada jawaban siswa yang mendapatkan skor 1 dalam menjawab soal nomor 3 terdapat kesalahan siswa dalam menjawab yaitu tidak benar dan tidak lengkap dalam membuat grafik. Hal tersebut dapat dilihat dari cara siswa menentukan skala yang tidak tetap pada setiap titik pada sumbu $x$ dan sumbu y.

Siswa kurang mampu merepresentasikan simbol-simbol atau angka dari pasangan himpunan terurut ke dalam sebuah koordinat kartesius dan juga grafik. Siswa sudah mengetahui bahwa cara menyelesaikan permasalahan dari bentuk pasangan himpunan terurut yang disajikan dalam bentuk tabel adalah dengan mengubah pasangan himpunan terurut tersebut ke dalam bentuk gambar koordinat kartesius kemudian membuat grafik penyelesaiannya, namun siswa tidak paham cara membuat koodinat kartesius yaitu dengan menentukan jarak yang sama dari setiap titik yang dimulai dari titik $(0,0)$ ke setiap titik selanjutnya pada sumbu $x$ dan $y$. 
Kesalahan ini dapat disebabkan karena siswa kurang memahami materi prasyarat yaitu garis bilangan. Dalam membuat garis bilangan diperlukan kemampuan merepresentasikan simbol-simbol bilangan bulat ke dalam bentuk gambar garis bilangan. Hal ini menunjukan bahwa siswa masih mengalami kesulitan dalam menggunakan representasi matematis dalam bentuk gambar atau grafik.

Dari penjelasan di atas terlihat kesalahan terbanyak siswa adalah pada saat menggambar titik pada grafik dan menentukan titik potong. Sebagian besar siswa dapat menggambar sumbu $x$ dan y tetapi salah menempatkan titik sehingga salah dalam menghubungkan kedua titik tersebut dengan sebuah garis. Ini berarti siswa tidak memahami cara membuat koordinat kartesius, tidak dapat menentukan titik pada grafik dan tidak memahami konsep bilangan bulat serta garis bilangan untuk menggambar sumbu $x$ dan sumbu $y$. Hal ini menunjukkan bahwa siswa belum mampu mengubah simbol-simbol matematis ke dalam bentuk gambar.

Pada soal nomor 3 untuk indikator representasi gambar, siswa yang mendapatkan skor 3 sebanyak 12 siswa, siswa yang mendapatkan skor 2 sebanyak 23 siswa, siswa yang mendapatkan skor 1 sebanyak 48 siswa dan sisanya yang mendapatkan skor 0 sebanyak 2 siswa. Berdasarkan hasil tersebut dapat kita lihat sebagian besar siswa mendapatkan skor 1 dan 2 pada indikator representasi gambar. Berdasarkan penjelasan di atas, dapat disimpulkan bahwa kemampuan siswa dalam menyelesaikan permasalahan matematika menggunakan representasi dalam bentuk gambar masih belum maksimal.

\section{Kemampuan representasi simbol (Symbolic Representation).}

Soal yang memperlihatkan bagaimana kemampuan representasi matematis dalam bentuk simbol adalah butir soal nomor 1 dan 4. Sebagai gambaran umum berikut ini disajikan soal nomor 1 dan 4 serta jawaban beberapa siswa dalam menjawab pertanyaan soal nomor 1 dan 4 .

\section{Pertanyaan nomor 1 : Umur Dani 5 tahun lebih tua dari umur Devi.}

Sedangkan jumlah umur mereka adalah 39 tahun. Buatlah model matematikanya!

Hitunglah berapa umur mereka masing-masing saat ini?

Berikut diberikan contoh jawaban yang diberikan oleh beberapa siswa untuk soal nomor 1:

Pada Gambar 4.3 siswa yang menjawab dengan mendapat skor 3 terlihat kemampuan siswa dalam menyelesaikan permasalahan matematika menggunakan representasi simbol, yaitu menggunakan variabel $x$ dan y untuk mengubah Dani dan Devi ke dalam model matematika. Terlihat juga siswa dapat memahami cara menyelesaikan permasalahan mengunakan system persamaan linear dua variabel. Hal in menunjukkan bahwa siswa memiliki kemampuan representasi matematis dalam bentuk symbol dengan baik.

Pada jawaban siswa yang mendapat skor 2 terlihat penggunaan symbol atau model matematika untuk menyelesaikan permasalahan terkait materi system persamaan linear dua variabel. Ketika menjumpai permasalahan

$$
\text { 46| Edisi } 3 \text { No. } 2 \text { Januari-Juli } 2021
$$


seperti pada soal nomor 1 tersebut, siswa sudah mengetahui bahwa langkah penyelesaiannya adalah dengan mengubah permasalahan ke dalam model matematika. Siswa mengubah apa yang diketahui dari soal menjadi simbol atau variabel sehingga dapat mempermudah siswa dalam mengoperasikannya ke dalam perhitungan matematis, akan tetapi pada jawaban siswa ini masih terdapat kekurangan yaitu siswa membuat persamaan linear hanya satu variabel. Variabel yang digunakan hanya variabel $\mathrm{n}$ saja untuk menggantikan Devi, sedangkan untuk Dani tidak ada variabel lain yang digunakan, hanya menggunakan substitusi variabel dari Devi, yaitu menjadi $n+5$. Hal ini menunjukkan kemampuan siswa dapat menggunakan representasi simbol dengan baik, namun kurang sesuai dengan materi persamaan linaer dua variabel.

Pada jawaban siswa yang mendapat skor 1 dalam menjawab soal nomor 1 adalah tidak membuat model matematika dari permasalahan yang diberikan meskipun jawaban dan hasil perhitungan siswa benar. Pada jawaban tipe ini siswa mampu memahami pertanyaan dan benar dalam perhitungan menggunakan cara di luar materi persamaan linear dua variabel. Hal ini menunjukan bahwa kemampuan siswa membuat model matematika pada materi sistem persamaan linear dua variabel masih kurang. Hal ini dapat disebabkan karena siswa kurang memahami definisi variabel dalam matematika sehingga siswa tidak bisa mengubah permasalahan menjadi kalimat atau model matematika.

\section{Pertanyaan nomor 4 : Pada sebuah peta terdapat tiga kota yaitu kota Magelang, Surakarta, dan Yogyakarta.}

Jika diketahui jarak dari Yogyakarta ke Surakarta pada peta adalah $4 \mathrm{~cm}$ dan jarak antara Yogyakarta dan Magelang adalah $3 \mathrm{~cm}$.

Diketahui arah dari Yogyakarta ke Surakarta berada tegak lurus dengan arah dari Yogyakarta ke Magelang. Jika skala pada peta adalah 1:200.000, berapakah jarak pada peta dan jarak sebenarnya antara Magelang dan Surakarta?

Berikut diberikan contoh jawaban yang diberikan oleh beberapa siswa untuk soal nomor 4 :

Gambar 4. 4 Beberapa Jawaban Siswa Pada Indikator Representasi Simbol Pada jawaban siswa yang mendapat skor 3 terlihat kemampuan siswa dalam menggunakan simbol untuk memecahkan masalah matematika. Siswa mampu menggunakan beberapa variabel untuk mewakili setiap jarak antar kota pada permasalahan yang diberikan. Variabel-variabel tersebut merupakan bentuk representasi simbol yang digunakan siswa untuk mewakilkan setiap jarak antar kota. Simbol-simbol daam bentuk variabel tersebut memudahkan siswa untuk melakukan operasi perhitungan dalam menyelesaikan permasalahan menggunakan teorema phytagoras. Hal ini menunjukkan siswa mampu menggunakan kemampuan representasi matematis pada indikator representasi simbol dengan baik.

Pada jawaban siswa yang mendapat skor 2 dalam menjawab soal nomor 4 terlihat siswa tidak menyajikan soal dalam model matematika dengan benar.

\section{7| Edisi $3 \quad$ No. $2 \quad$ Januari-Juli 20221}


Sehingga pada proses perhitungan terlihat siswa tidak menggunakan variable untuk menjelaskan informasi pada soal. Siswa langsung menghitung angkaangka yang diketahui saja. Hal ini memungkinkan siswa tidak paham dengan pekerjaannya. Pada jawaban ini siswa sudah menggunakan teorema phytagoras dan melakukan perhitungan dengan benar, meskipun tidak menyelesaikan satu perintah soal untuk menentukan jarak pada peta. Jawaban siswa tipe ini juga menunjukan kurangnya kemampuan siswa dalam membuat model matematika yang berarti bahwa siswa masih mengalami kesulitan dalam menggunakan representasi matematis dalam bentuk simbol.

Pada jawaban siswa yang mendapat skor 1 dalam menjawab soal nomor 4 terlihat siswa tidak menggunakan teorema phytagoras untuk menentukan jarak antar kota pada peta, kemudian terdapat kesalahan dalam menjumlahkan jarak yang diketahui untuk membagi skala sehingga hasil akhir perhitungan mereka pun menjadi salah. Perhitungan yang salah dari penggunaan model matematika ini menunjukan bahwa kemampuan representasi dalam bentuk simbol atau model matematika masih rendah. Hal ini dapat disebabkan karena siswa tidak memahami teorema Phytagoras yang menyatakan bahwa jumlah kuadrat sisi-sisi segitiga siku-siku sama dengan kuadrat sisi miringnya, sehingga siswa tidak menggunakan teorema Phytagoras untuk menentukan jarak sisi miring pada peta. Siswa juga tidak memahami materi perbandingan skala peta.

Dari penjelasan di atas terlihat sebagian siswa sudah mampu menggunakan representasi simbol meskipun beberapa diantaranya masih kurang tepat. Kesalahan siswa pada umumnya terlihat pada saat mengubah permasalahan ke dalam model matematika. Terlihat kurangnnya penggunaan variabel dalam membuat model matematika dari permasalahan yang diketahui. Kurangnya pemahaman tentang definisi variabel dapat menjadi salah satu penyebab hal tersebut.

Pada soal nomor 1 dan 4 untuk indikator representasi simbol, siswa yang mendapatkan skor 3 sebanyak 9 jawaban ( 6 siswa pada nomor 1 dan 3 siswa pada nomor 4), siswa yang mendapatkan skor 2 sebanyak 141 jawaban (75 siswa pada nomor 1 dan 66 siswa pada nomor 4), siswa yang mendapatkan skor 1 sebanyak 14 jawaban ( 2 siswa pada nomor 1 dan 12 siswa pada nomor 4) dan sisanya yang mendapatkan skor 0 sebanyak 6 jawaban (2 siswa pada nomor 1 dan 4 siswa pada nomor 4). Berdasarkan hasil tersebut dapat kita lihat sebagian besar siswa mendapatkan skor cukup baik pada indikator representasi simbol, sehingga dapat disimpulkan bahwa kemampuan siswa dalam menyelesaikan permasalahan matematika menggunakan representasi dalam bentuk simbol sudah cukup memuaskan.

\section{Kemampuan representasi verbal (Verbal Representation).}

Soal yang memperlihatkan bagaimana kemampuan representasi matematis dalam bentuk kata-kata adalah butir soal nomor 2 dan 6. Sebagai gambaran umum berikut ini disajikan soal nomor 2 dan 6 serta jawaban beberapa siswa dalam menjawab pertanyaan soal nomor 2 dan 6 .

Pertanyaan : Perhatikan gambar di bawah ini. 


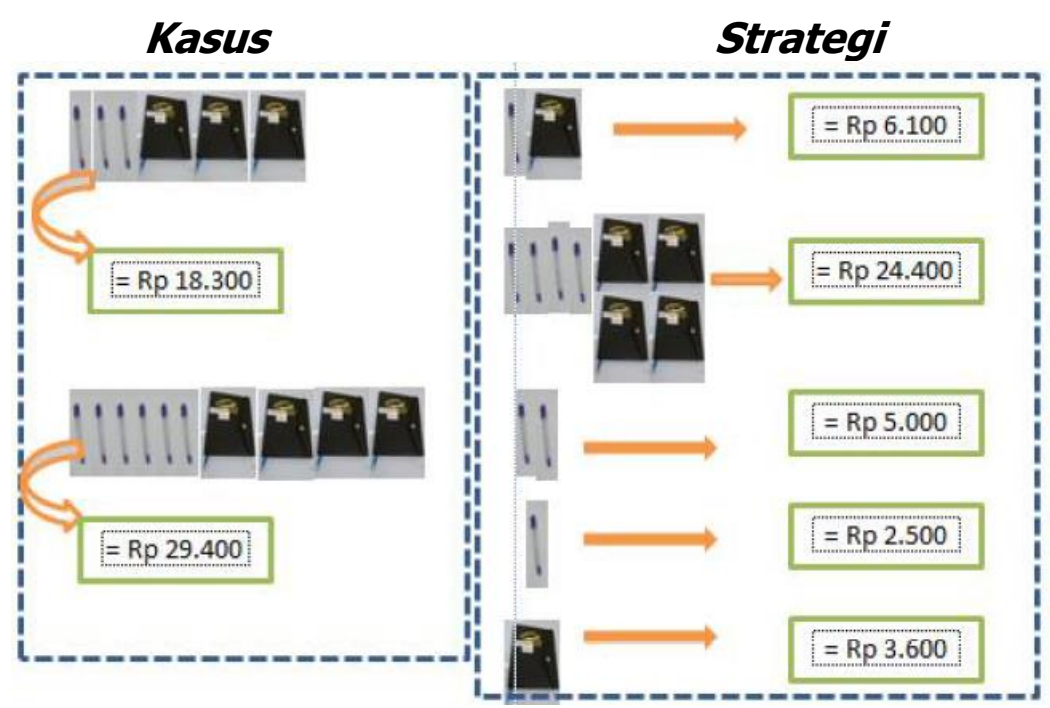

Gambar tersebut menjelaskan strategi yang digunakan oleh Rahmat untuk menentukan harga masingmasing buku dan pulpen. Jelaskan dengan bahasamu mengenai srategi yang digunakan Rahmat untuk menentukan harga sebuah buku dan sebuah pulpen!

Berikut diberikan contoh jawaban yang diberikan oleh beberapa siswa untuk soal nomor 2 :

Pada jawaban siswa yang mendapat skor 3 terlihat siswa menjelaskan secara rinci setiap langkah yang ada pada soal dengan mengaitkan kasus yang ada dengan strategi yang digunakan. Hal ini menunjukkan bahwa siswa memang benar paham dan tahu darimana hasil yang didapat pada setiap langkah strategi yang digunakan Rahmat yang ada pada soal dan mampu menerjemahkannya dalam kata-kata sendiri.

Pada jawaban siswa yang mendapat skor 2 dalam menjawab soal nomor 2 terlihat siswa tidak menjelaskan cara menentukan harga masing-masing buku dan pulpen sesuai dengan alur strategi menentukan harga sesuai gambar yang diperlihatkan. Mereka menggunakan keterangan hasil yang didapat yaitu harga satu buku dan satu pulpen untuk memecahkan kasus pada pertanyaan, sedangkan maksud dari perintah soal adalah menjelaskan alur menemukan harga satuan buku dan pulpen dari beberapa harga buku dan pulpen yang telah diketahui dari kasus dalam soal bukan dari strategi yang diperlihatkan. Jawaban siswa tipe ini sudah menunjukan kemampuan representasi dari sebuah gambar ke dalam bentuk katakata dengan cukup baik meskipun masih kurang tepat dalam memahami alur gambar. Pada jawaban siswa yang mendapat skor 1 terlihat siswa dalam menjawab soal nomor 2 terlihat siswa tidak memahami maksud dari gambar yang diberikan. Siswa menjawab dengan kata-kata yang tidak sistematis dan tidak logis.

Selain nomor 2, soal nomor 6 juga merupakan soal yang digunakan untuk mengukur kemampuan representasi matemati siswa pada indikator representasi verbal. Sebagai gambaran umum berikut ini disajikan soal nomor 2 dan 6 serta jawaban beberapa siswa dalam menjawab pertanyaan soal nomor 2 dan 6 . 


\section{Pertanyaan nomor 6 : Sebuah kapal nelayan bertolak dari pelabuhan untuk menangkap gerombolan ikan tongkol yang biasanya berkumpul di suatu titik di lepas pantai.}

Agar dapat menangkap ikan lebih banyak, kapal nelayan tidak langsung menuju tempat tersebut melainkan berlayar melewati jalur baru yakni $12 \mathrm{~km}$ ke barat kemudian $35 \mathrm{~km}$ ke selatan. Berapa selisih jarak yang ditempuh kapal menggunakan jalur baru dengan jarak yang ditempuh jika melewati jalur lurus?

Berikut diberikan contoh jawaban yang diberikan oleh beberapa siswa untuk soal nomor 2 :

Pada jawaban siswa yang mendpat skor 3 terlihat bahwa siswa mampu menyelesaikan permasalahan yang ada. Siswa mampu menggunakan interpretasi dari perhitungan yang didapat, yaitu menentukan selisih jarak dari dua jalur yang ditanyakan kemudian menyampaikannya dengan bahasa mereka.

Pada jawaban siswa yang mendapat skor 2 dalam menjawab soal nomor 6 adalah tidak memberikan penjelasan dari jawaban mereka menggunakan katakata mereka sendiri, meskipun hasil perhitungan mereka benar dan menyelesaikan perintah soal untuk menentukan selisih kedua jalur kapal. Pada tipe jawaban seperti ini siswa juga tidak memperlihatkan kemampuan representasi dalam bentuk kata-kata.

Pada jawaban siswa yang mendapat skor 1 dalam menjawab soal nomor 6 terlihat langkah yang tidak selesai pada saat melakukan perhitungan pada rumus phytagoras, siswa tidak menghitung nilai dari akar kuadrat yang sudah didapat.

Mereka juga tidak menyelesaikan jawaban mereka untuk menentukan selisih dari dua jalur yang harus mereka hitung. Mereka tidak memperlihatkan kemampuan representasi dalam bentuk kata-kata. Kesalahan ini dapat disebabkan karena siswa tidak paham operasi aljabar pada bilangan kuadrat.

Dari penjelasan di atas terlihat sebagian siswa sudah mampu menggunakan representasi verbal meskipun beberapa diantaranya masih belum bisa menyampaikan ide matematisnya dengan bahasa sendiri. Kesalahan siswa pada umumnya terlihat pada saat memahami permasalahan yang terdapat pada soal sehingga sebagian tidak bisa menyampaikan ide matematisnya ke dalam katakata dan bahasa mereka sendiri.

Pada soal nomor 2 dan 6, siswa yang mendapatkan skor 3 sebanyak 18 jawaban (18 siswa pada nomor 2 dan 0 siswa pada nomor 6), siswa yang mendapatkan skor 2 sebanyak 116 jawaban (52 siswa pada nomor 2 dan 64 siswa pada nomor 6), siswa yang mendapatkan skor 1 sebanyak 25 jawaban (7 siswa pada nomor 2 dan 18 siswa pada nomor 6) dan sisanya yang mendapatkan skor 0 sebanyak 11 jawaban (8 siswa pada nomor 2 dan 3 siswa pada nomor 6).

Berdasarkan hasil tersebut dapat kita lihat sebagian besar siswa mendapatkan skor cukup baik pada indikator representasi verbal, sehingga dapat disimpulkan bahwa kemampuan siswa dalam menyelesaikan 
permasalahan matematika menggunakan representasi dalam bentuk verbal sudah cukup memuaskan.

Selain pengambilan data melalui tes kemampuan representasi matematis, peneliti juga melakukan wawancara kepada guru matematika kelas VIII SMP Negeri 2 Woja. Wawancara dilakukan untuk memperoleh data tambahan mengenai kemampuan representasi matematis siswa kelas VIII di SMP Negeri 2 Woja.

Berdasarkan hasil wawancara terhadap guru yang mengajar matematika kelas VIII SMP Negeri 2 Woja, diperoleh informasi mengenai keadaan pembelajaran matematika dan kemampuan representasi matematis siswa sebagai berikut :

1. Sikap siswa dalam pembelajaran matematika masih kurang terlihat antusiasme siswa karena hanya sedikit saja yang benar-benar memperhatikan dan aktif bertanya saat pelajaran matematika. Masih banyak siswa yang merasa kesulitan dalam belajar matematika. Kesulitan mereka juga bermacammacam, ada yang kesulitan dalam menghitung, menghapal rumus, memahami konsep matematika, memahami permasalahan di kehidupan sehari-hari dan masih banyak lagi. Kesulitankesulitan tersebut dapat disebabkan salah satunya karena kurangnya penggunaan kemampuan representasi dalam pembelajaran matematika.

2. Metode pembelajaran yang kurang bervariatif juga menyebabkan kurangnya minat siswa dalam belajar matematika. Metode pembelajaran yang lebih sering digunakan adalah metode ceramah dan latihan soal-soal. Hal ini disebabkan karena karena keterbatasan guru dalam mempelajari metodemetode baru dan juga tuntutan kurikulum dengan banyaknya materi yang harus diajarkan tetapi alokasi waktunya masih terbatas. Melalui metode pembelajaran seperti itu biasanya minim penggunaan representasi dalam pembelajaran matematika.

3. Kemampuan representasi matematis siswa pun terlihat masih kurang, dilihat dari saat mengerjakan soal-soal sebagian besar mengikuti cara yang guru ajarkan saja. Pada saat pembelajaran juga siswa cenderung mendengarkan saja, masih kurang sering dalam mengemukakan gagasannya.

4. Kemampuan representasi matematis termasuk penting untuk siswa dalam belajar matematika, karena siswa punya cara masing-masing dalam menyampaikan pemahamannya. Ada yang lebih paham jika dijelaskan dengan gambar, ada yang lebih paham menggunakan simbol-simbol matematika. Beberapa materi juga perlu menggunakan kemampuan representasi yang berbeda-beda.

\section{KESIMPULAN}

Berdasarkan temuan dan pembahasan, maka penelitian ini memiliki kesimpulan sebagai berikut: Kemampuan representasi matematis siswa secara keseluruhan memiliki nilai rata-rata sebesar 59,87; Kemampuan representasi matematis pada indikator representasi gambar (pictorial representation) memiliki 
rata-rata sebesar 50,98. Hampir setengah dari jumlah siswa masih belum mampu mengubah simbol-simbol matematika menjadi bentuk gambar pada grafik untuk menyelesaikan permasalahan matematika. Kemampuan representasi matematis siswa pada indikator representasi gambar masih berada di bawah rata-rata. Kemampuan representasi matematis pada indikator representasi symbol (symbolic representation) memiliki rata-rata sebesar 65,66 . Kemampuan representasi matematis siswa pada indikator representasi simbol lebih tinggi dari indikator gambar dan verbal. Sebagian besar siswa sudah mampu menggunakan simbolsimbol dan model matematika untuk menyelesaikan masalah matematika sehingga mendapatkan skor cukup baik pada indikator representasi simbol. Kemampuan representasi matematis pada indikator representasi verbal (verbal representation) memiliki rata-rata sebesar 62,45 . Sebagian siswa sudah mampu menggunakan representasi verbal namun beberapa diantaranya masih belum bisa menyampaikan ide matematisnya dengan bahasa sendiri. Kesalahan-kesalahan siswa pada indikator representasi gambar berupa kesalahan menentukan titik pada grafik yang berarti siswa belum mampu mengubah simbol-simbol matematis ke dalam bentuk gambar untuk menyelesaikan masalah berkaitan dengan sistem persamaan linear dua variabel; pada indikator representasi simbol beberapa kesalahan siswa dalam menyelesaikan permasalahan matematika berkaitan sistem persamaan linear dua variabel yaitu tidak menggunakan dua variabel untuk membuat model matematika dari permasalahan yang ada dan berkaitan dengan materi teorema phytagoras siswa tidak menunjukkan kepahaman dalam menggunakan simbol-simbol matematika untuk mewakili setiap sisi pada segitiga; pada indikator representasi verbal kesalahan siswa berupa penyusunan kata-kata yang tidak sistematis sehingga tidak dapat merepresentasikan ide matematisnya. 


\section{DAFTAR RUJUKAN}

Arikunto, Suharsimi. Dasar-Dasar Evaluasi Pendidikan. Jakarta: Bumi Aksara, 2006.

Gagatsis, Athanasios and Iliada Elia. The Effects Of Different Modes Of Representation On Mathematical Problem Solving. Proceedings of the 28th Conference of the International Group for the Psychology of Mathematics Education. Nicosia: Department of Education, University of Cyprus, 2004.

Godino dan Font. The Theory of Representations as Viewed from the OntoSemiotic pproach to Mathematics Education. Mediterranean Journal for Research in Mathematics Education Vol. 9.

Goldin, Gerald and Nina Shteingold. System of Representation and The Development of Mathematical dalam Albert A Cuoco, Frances R Cucio, The Roles of Representation in School Mathematics. National Council of Teachers of Mathematics: 2010.

Poernomo, Erdy. Pengaruh Pembelajaran Kooperatif Strategi Think-Talk-Write Menggunakan Masalah Kontekstual Terhadap Kemampuan Representasi Matematis Siswa. Skripsi Jurusan Pendidikan Matematika UIN Syarif Hidayatullah Jakarta: 2014, tidak dipublikasikan.

Hardiyaningsih, Endah. Analisis Kemampuan Representasi Multiple Matematis Siswa Sekolah Menengah Pertama Negeri Di Jakarta Selatan. Skripsi Jurusan Pendidikan Matematika UIN Syarif Hidayatullah Jakarta: 2017, tidak dipublikasikan.

Kartini. Peranan Representasi dalam Pembelajaran Matematika. Makalah disampaikan pada Seminar Nasional Matematika dan Pendidikan Matematika, FMIPA UNY, Yogyakarta, 2009.

Komalasari, L, I. (2020). Analisis Tingkat Kesulitan Siswa dlama Kemampuan Menyelesaikan Masalah Matematika Materi Persamaan Kuadrat. Histogram: Jurnal Pendidikan Matematika, 4(1), 139 - 150, doi: http://dx.doi.org/10.31100/histogram.v4i1.566 Permalink/DOI: http://dx.doi.org/10.31100/histogram.v4i1.566

Lawshe, C. H. A quantitative Approach to Content Validity. Personel Psychology, INC: 1975.

Lestari, Karunia Eka dan Mokhammad Ridwan Yudhanegara. Penelitian Pendidikan Matematika. Bandung: PT Refika Aditama, 2015.

Pape dan Tchoshanov. The Role of Representation(s) in Developing Mathematical understanding. Theory Into Practice Vol. 40: Spring 2001.

Syofian Siregar. Statistika Deskriptif untuk Penelitian. Jakarta: Rajawali pers, 2010.

The National Council of Teachers of Mathematics. Principles and Standards for School Mathematics. USA: NCTM, 2000.

Verschaffel, Lieven et al. Use of Representation in Reasoning and Problem Solving. USA: Routledge, 2010. 
ISSN Cetak: 2685-5542

Jurnal Lentera

ISSN Online: 2685-5550

Wardhani, Sri. Instrumen Penilaian Hasil Belajar Matematika SMP. Jakarta: Pusat Pengembangan dan Pemberdayaan Pendidik dan Tenaga Kependidikan Matematika, 2011. 